\title{
ABBREVIATIONS FOR MANN CITATIONS
}

B Thomas Mann: "On Myself" and Other Princeton Lectures: An Annotated Edition Based on Mann's Lecture Typescripts, ed. James N. Bade. Frankfurt am Main: Peter Lang, 1996.

BR.H Letters of Heinrich and Thomas Mann, 1900-1949, ed. Hans Wysling, tr. Don Reneau, with additional translations by Richard and Clara Winston. Berkeley, CA: University of California Press, 1998.

BR.M Thomas Mann und Agnes Meyer: Briefwechsel 1937-1955, ed. Hans Rudolf Vaget. Frankfurt am Main: S. Fischer, 1992.

C The City of Man: A Declaration on World Democracy. New York: Viking Press, 1940.

D Thomas Mann Diaries 1918-1939, tr. Richard and Clara Winston. New York: Harry N. Abrams, 1982.

E Essays, ed. Hermann Kurzke and Stephan Stachorski. 6 vols. Frankfurt am Main: S. Fischer, 1993-97 (volume and page numbers are indicated in Arabic numerals).

EF An Exceptional Friendship: The Correspondence of Erich Kahler and Thomas Mann, tr. Richard and Clara Winston. Ithaca, NY: Cornell University Press, 1975.

GKFA Thomas Mann, Große kommentierte Frankfurter Ausgabe —Werke, Briefe, Tagebücher, ed. Heinrich Detering, Eckhard Heftrich, Hermann Kurzke, Terence J. Reed, Thomas Sprecher, Hans Rudolf Vaget, and Ruprecht Wimmer in collaboration with the Thomas-Mann-Archiv of the ETH, Zurich. 17 vols. Frankfurt am Main: S. Fischer, 2002-(volume and page numbers are indicated in Arabic numerals).

GW Thomas Mann, Gesammelte Werke in dreizehn Bänden, ed. Peter de Mendelssohn. 13 vols. Frankfurt am Main: S. Fischer, 1974 (volume and page numbers are indicated in Arabic numerals).

H Klaus Harpprecht, Thomas Mann: Eine Biographie. Reinbek bei Hamburg: Rowohlt, 1995 .

L The Letters of Thomas Mann, 1889-1955 [a selection], tr. Richard and Clara Winston. New York: Knopf, 1970.

LW Lotte in Weimar, Roman, ed. Werner Frizen. GKFA 9.1. Frankfurt am Main: S. Fischer, 2003.

LWA The Beloved Returns: Lotte in Weimar, tr. H. T. Lowe-Porter. New York: Knopf, 1940.

N The Letters of Thomas Mann to Caroline Newton. Princeton, NJ: Princeton University Press, 1971.

T3 Thomas Mann, Tagebücher 1937-1939, ed. Peter de Mendelssohn. Frankfurt am Main: S. Fischer, 1980. 
T4 Thomas Mann, Tagebücher 1940-1943, ed. Peter de Mendelssohn. Frankfurt am Main: S. Fischer, 1982.

TB Tobias Boes, Thomas Mann's War: Literature, Politics, and the World Republic of Letters. Ithaca, NY: Cornell University Press, 2019.

VA Hans Rudolf Vaget, Thomas Mann, der Amerikaner. Leben und Werk im amerikanischen Exil 1938-1951. Frankfurt am Main: S. Fischer, 2011.

V Hans Rudolf Vaget, “'The Best of Worlds,' Thomas Mann in Princeton.” The Princeton University Library Chronicle 75, no. 1 (Autumn 2013): 9-37. 
THE MIND IN EXILE 
